\title{
The Paradox of Nicolae Ceausescu's Foreign Policy and Several Reasons for the Deterioration of the International Image of His Regime
}

\author{
Hadrian Gorun, (Associate Professor PhD) \\ "Constantin Brancusi" University of Targu-Jiu, Romania \\ Lucretia-Ileana Branescu (PhD candidate) \\ University of Craiova, Romania
}

Doi:10.19044/esj.2018.v14n29p75 URL:http://dx.doi.org/10.19044/esj.2018.v14n29p75

\begin{abstract}
This short article attempts to find and highlight the most important reasons that determined the deterioration of the international imagine of the communist regime from Nicolae Ceausescu's Romania. Although after 1968, - the year when the Romanian leader publicly condemned Czechoslovakia's invasion by the Red Army- Romania's image in the Western countries was very good, during the $80 \mathrm{~s}$ the whole capital of sympathy completely disappeared. Nicolae Ceausescu's anti-Soviet foreign policy made him a socalled "spoiled child" of the West. In 1989, the Romanian dictator remained the only Stalinist leader from European countries, paradoxically an anti-Soviet Stalinist leader.

In our opinion there were three very important events that determined the irreversible degradation of the regime's image abroad: Helsinki Final Act in 1975; General Ion Mihai Pacepa's (vice-leader of Foreign Information Department of Romanian Intelligence) run to the USA and last but not the least, Mikhail Gorbachev's election as general secretary of the Communist Party of the Soviet Union. (CPSU) We started from the hypothesis that these three moments were somehow decisive for Ceausescu's decline in the eyes of his own people and mainly in international relations. From methodological point of view we tried to explain briefly how and in what measure the three mentioned events and their consequences changed maybe irreversibly the image of Romanian dictator mainly abroad. We tried also to make a short comparison between Ceausescu's situation in 1968 and his position in the 1980 's. We could conclude that evolution of the events confirmed that one of the most important blows for Romanian dictator was Gorbachev's election. However we do not need to overrate this aspect. The international and regional context at the end of 1980's was decisive. The end of the Cold War and
\end{abstract}


refolutions from Central and Eastern Europe made impossible the survival of the last Stalinist regime.

Keywords: Nicolae Ceausescu, Mikhail Gorbachev, neo-stalinism, foreign policy, paradox.

\section{Introduction. A few methodological aspects}

Did George Bush and Mikhail Gorbachev, the most powerful men of the planet, decide at the beginning of December 1989, with the occasion of the meeting in Malta on "Maxim Gorki" ship, to get rid of Nicolae Ceauşescu? At that moment, Ceausescu remained the last and the only one Stalinist of Europe. (For the communist regime, Nicolae Ceauseascu's era, see among others, Gorun A., 2012: 108-79; Shafir, 1985; Jowitt, 1971; Burakowski, 2011; Deletant, 1997; Tismaneanu, 2005; Kunze, 2002; Gabanyi, 2003; Georgescu, 1992; Campeanu, 2002; Pacepa, 1993).

Perhaps a definitive elucidation of this thorny issue will only occur when a declassification of several archive documents will be made. And maybe not even then. Why? Because any document issued by a certain authority contains only the information that authority wants to leave behind for posterity. That document is a materialisation of the power's discourse. Moreover, $a$ priori, one cannot talk about objectivity in history. There is only subjectivity, which can be good subjectivity or bad subjectivity (Gorun G., 2008: 116-10). We could conclude there is no true objectivity in humanities and social sciences. Starting from this premise, we attempted to make a short analysis of Nicolae Ceausescu's foreign policy. We took into consideration particularly the main reasons, which in our opinion determined the degradation of the international image and finally the complete isolation of the regime. From methodological point of view we tried to explain briefly how and in what measure three international events and their consequences changed maybe irreversibly the image of Romanian dictator mainly abroad. We think about Helsinki Final Act in 1975, General Ion Mihai Pacepa's run to the USA and last but not the least, Mikhail Gorbachev's election as general secretary of the Communist Party of the Soviet Union. We tried to find the significance and to explain why each of these events represented a real political blow for the dictator of Bucharest. In our opinion the consequences of the last event (Gorbachev's election) was among the most important cause for Ceausescu's "regime" collapse.

We attempted also to make a short comparison between the situation of the Romanian leader in 1968 and his position in the 1980's. We strived to identify the main reason for which the popularity level of Ceausescu's regime decreased so much. In the year 1968, in August, Romanian leader was at the apogee of his popularity in Romania and in international relations as well. Due 
to his courageous attitude towards Kremlin, the Western powers perceived somehow Romanian leader as a kind of a new Iosip Broz Tito.

\section{Several considerations about the nature of Nicolae Ceausescu's regime}

Nicolae Ceausescu gradually became, especially in the second half of the 1980s, an undesirable leader for both the United States and Kremlin. The huge capital of popularity and sympathy, acquired by the General Secretary of the Communist Party after 1968 [when not only that he declined Romania's involvement in the invasion of Czechoslovakia (Retegan, 1998) but, moreover, he publicly condemned the aggression] began to evaporate progressively. The anti- Sovietism policy carried out consistently, will become obsolete. We must mention that Nicolae Ceauşescu will adopt a completely different attitude in 1989 when he insisted for a force intervention of the Warsaw Treaty Organization in Poland and Hungary, where internal political developments threatened the fate of socialism.

A paradox of Ceauşescu's politics, rightly pointed out by the political scientist Vladimir Tismaneanu (Tismaneanu, 2005: 260-223), is that even though an anti-Soviet leader until the end in his foreign policy, internally, the Romanian leader turned out to be a fervent Stalinist. In fact, an anti-Soviet Stalinist. We could say then in the eyes of his own people Nicolae Ceausescu evolved or better said involved from "the most beloved son" to the "the most hated" man in Romania. Nicolae Ceausescu's neo-stalinism became obvious especially in 1980's, although we could perceive the first signs even after 1971, the year when he visited Mao Zedong's China and North Korea. After that he bagan a kind of "cultural revolution", following Chinese pattern. During 1980's the most draconian measures were implemented because the dictator intended to pay all the external debt of the Romanian state. In this way, he wanted to affirm Romania's independence in international affairs. Unfortunately the costs and the sacrifices of the Romanian population were huge. The lack of food, of the goods absolutely necessary for survival, the interruption of electricity supply and a lot of other unpopular measures made Nicolae Ceausescu a dictator and a tyrant in the eyes of his own people. After August 1968, the situation was totally different. The people loved and appreciated him as a great leader. In 1980's, only some high ranking officials party (the so-called nomenklatura) and a part of Securitate (the secret political police) really supported him. They were among very few categories that enjoyed wealth and privileges.

Some historians have spoken of the practice of a terror for prophylactic reasons, or of a non-terrorist neo-Stalinism (Deletant, 2006: 266-180). Indeed, the intensity of physical terror has diminished compared to the Gheorghe Gheorghiu-Dej era, but the psychic terror was exerted in the "Golden Age", with few active opponents, such as Vasile Paraschiv. These opponents had 
been subjected to psychiatric "treatments". In fact, the diabolical goal was to reduce the "patient" to the so-called vegetable condition.

\section{From Helsinki Final Act to the election of the Reformer Mihail Gorbachev as General Secretary of the CPSU}

In our opinion, at least three significant international events caused gradual decline of the Ceauşescu's regime and ultimately international isolation and, implicitly, its collapse (Gorun H., 2012: 220-215). We do not emphasize here internal realities such as the serious deterioration of the Romanians' living conditions since the end of the 70s (worsening caused by the obduracy with which the dictator was holding to the death to pay foreign debt), the systematization program, the omnipresence and the omnipotence of political police, control over privacy (Kligman, 2000) etc..

The first event: Helsinki Final Act (Securitatea si cooperarea in Europa. Documente 1972-1989, 1991) in 1975, with its basket concerning human rights. In principle, the international community could supervise the respect of the human rights in communist countries from Europe and exert pressures on Ceausescu's "regime". But the Bucharest authorities used the non-interference principle in the internal affairs of states in order to circumvent this provision. This principle allowed them to flagrantly violate fundamental rights and freedoms. The sovereignty principle was used by Romanian leader in his well-known speeches pronounced in August 1968 and in December 1989. In fact, nationalism was one of the main features of his policy. But the internal and mainly external contexts were completely different in 1989. The foreign policy process depends upon some elements such as the type, the nature of the political regimes. Nicolae Ceausescu's Romania was a totalitarian communist state. In a non-democratic regime, the only one real foreign policy decision maker is the dictator himself. Moreover, the leader of Bucharest was known for some paranoid tendencies. So the whole politics of the state (here included foreign policy) was headed by him. He established all foreign policy objectives and adopted the essential decisions. Thus we could say that the Ministry of Foreign Affairs had only a formal, decorative role. In 1968, Nicolae Ceausescu valorized an important event of the international relations. Condemning the invasion of Czechoslovakia he took advantages from an external event in order to strengthen his internal position and abroad popularity. Since 1968, Romanian leader has remained loyal to autonomous policy towards Moscow.

In 1978 however, a second major event took place. The General Ion Mihai Pacepa (Pacepa,1992) [vice-leader of Foreign Information Department of Romanian Intelligence] left Romania for United States of America. This "act of treachery" in favor of the "American imperialists" affected Nicolae Ceauşescu and unsettled a lot Romanian Securitate. Pacepa's book, Orizonturi 
rosii [Red Horizons], arrived later on President Ronald Reagan's desk. Very interested, the president read it and spoke a memorable statement: "This will be my Bible (my handbook) in relations with communist dictators" (Kunze, 2002: 428).

The authorities from Bucharest were optimistic after the Republican Reagan won the presidential elections in November 1980, because they were convinced that Republicans loved Romania, since Richard Nixon and Gerald Ford had visited Ceausescu (Ibidem: 418-415).

What is right, Reagan's vice-president, George Bush met Romanian president in Bucharest, but the international realities in the early 1980s were still somehow favorable to Ceausescu. The U. S. -Soviet bilateral relations had deteriorated rapidly following the Soviet military intervention in Afghanistan in December 1979, the second Cold War being underway. For these reasons, the U.S. Vice-President at that time had a rather positive attitude towards Ceausescu, praising him for his independent tendencies towards Moscow. The communist leader of Bucharest tried to maintain his image of disobedient leader towards Kremlin and thus to improve the relations with Washington and obtain economic aid.

But after 1985, the international context no longer evolved in the favor of Romania's leader (Gorun H. , 2012: 218). The third and perhaps the most important event was the election of the reformer Mikhail Sergheevici Gorbachev as General Secretary of the C.P.S.U. The appointment of the future architect of glasnost and perestroika in that position generated the gradual improvement of relations between Kremlin and Washington. The two world superpowers have passed from confrontation to cooperation, from fear and threats to dialogue and negotiation (Gaddis, 2009). For the United States and the whole West, the position of independence or extended autonomy towards the Soviet Union had become anachronical. Ceausescu continued to maintain this policy in order to disagree with Gorbachev and show his opposition to genuine internal reforms. It is obvious that he intended to impose a Stalinist internal policy. And the relations of Romanian leader with Gorbachev (Burakowski, 2011: 338-326) have been strained all over the nearly five years (since 1985 to December 1989). The leader of Kremlin wanted to reform communism. He was sure that reforms could save the communist system. $\mathrm{He}$ denounced Stalinism, but he has always appealed to Marxism-Leninism. On the other hand, Romanian dictator was aware that communism could not be reformed. Trying to reform communism means the dissolution of the system. The reform is not compatible with a totalitarian, monolithic regime. So, the relations between a reformist and a conservative communist could not improve, but they worsened. Ceausescu was also angry because the general secretary of CPSU represented one of the causes for the degradation of relations with US.. 


\section{Romania's complete isolation in the last years of communism. Did Mikhail Gorbachev and George Bush discuss in Malta about Ceausescu's removal?}

To Nicolae Ceausescu may be reproached a kind of political autism, remaining faithful to a political line that had brought him praise all over the world more than 15 years ago. But after 1985, and even more in the year 1989, the reality was quite different. The Socialist Republic of Romania was internationally isolated; the only states with which the regime from Bucharest still had good relations were North Korea, Cuba, People's Republic of China and the countries from the third world.

In 1989, the wind of change (to paraphrase a famous song by German band Scorpions) was blowing more and more strongly in the Central European states. In Socialist Republic of Romania, the "Golden Age" and the Leader were living their last months. "Refolutions" (Garton Ash, 1999: 14-13) as the political scientist and sociologist Timothy Garton Ash called them, in his book The Magic Lantern [namely popular movements, immediately followed by extensive reform programs or concurrently with them] succeeded in Poland, Hungary and Czechoslovakia. On November 9, 1989, the Berlin Wall, the symbol of Europe's and world's division, collapsed. The refractories Erich Honecker, in the German Democratic Republic, and Todor Jivkov, in Bulgaria, had been removed. Thus, as the historian Dumitru Preda pointed out, everything was meant to be carried out in accordance with the principle of domino (Preda, Retegan, 2000).

Nicolae Ceauşescu, however, was acting in another film, in which he wanted to be at the same time director and actor. Still, in the summer of 1989, in an interview with an American journalist, he declared himself an admirer of Iosif Vissarionovici Stalin (Evenimentul Zilei, 2009). Moreover, he welcomed the bloody repression measures of the demonstrators in the Tiananmen Square by the Communist power of Beijing. He cynically commented: "the duty of the students is to learn, and that of the government is to keep order" (Ibidem). Ceauşescu's clinging to power in his last days is therefore explicable, even if we only consider this statement. His attitude was ultimately fatal.

At the end of this article, we return to the question in the first paragraph. The opinions are divided. Alex Mihai Stoenescu referred to a bargaining between Bush and Gorbachev in Malta (Stoenescu, 2009; Idem, 2005; Cartianu, 2010).

The Soviet leader would have given free hand for a U.S. intervention in Panama to remove General Manuel Noriega's corrupt regime. Instead, the Soviet Union would have had a free hand on Romania. The Head of the State Security Department, Iulian Vlad, is considered to have informed the General Secretary of the Communist Party about the decision of superpower leaders to get rid of him. Moreover, in favor of the A.M. Stoenescu's valorisation it 
pleads the insistence with that the Party's official newspaper, Scinteia, has published - after the outbreak of the Romanian Revolution in Timişoara information about the realities of Panama. The articles condemned the interference of the great powers in the affairs of small states, the violation of the sovereignty and independence of the latter. Shortly after the GorbachevBush meeting in Malta, Ceausescu visited Moscow, and in a discussion with the Soviet leader, the Romanian president proposed that the discussion and solving of some problems be postponed to January 1990. The answer of the General Secretary of the USSR it remains very enigmatic: "Let us live by January 9..." (Sandulescu, 1996 : 292; Kunze, 2002: 458-456).

Yet the Americans Michael Beschloss and Strobe Talbott in At the Highest Levels. Inside Story of the End of the Cold War, have denied the idea that in Malta, Bush and Gorbachev would have set up the fate of Romania. (Beschloss, Talbott, 1993) The two scholars argued that the superpowers were less interested in small powers, the roles of the latter being insignificant in the international policy strategies of the former. Moreover, the two leaders, that of the White House and that of Kremlin, would have publicly declared that they did not discuss about Romania between December 2 and December 3, 1989. (Ibidem)

However, it is not without significance that before Nicolae and Elena Ceausescu being executed on December 25, 1989, the United States of America would have tried to offer political asylum to the two. Significant personalities of American political life, such as George Schultz, Secretary of State during Ronald Reagan's administration, and Henry Kissinger, former Richard Nixon's national security adviser, insisted on political asylum. In the summer of 1989, Ceausescu, at the George Bush's insistence agreed to give up capital punishment in respect to the diplomat Mircea Raceanu. The latter had been told that he had committed espionage in favor of the United States (Cartianu, 2010).

In December 1989, the desire of some American circles to save the Romanian dictator can also be seen as a reward for his leniency gesture made a few months ago. The neo-communist regime in Bucharest, however, categorically rejected the American proposal.

\section{Conclusion}

The three reasons mentioned in this short paper determined the international deterioration of Nicolae Ceausescu's regime and also weakened its position. In our opinion, Mikhail Gorbachev's election as head of Soviet Communist Party represents probably the fondamental cause. However, we do not have to overrate this aspect. We need to take into consideration the international context in the late 1980's, the improvement of the bilateral relations between Moscow and Washington and, as a consequence, the end of 
the ideological conflict. The Cold War will be over soon. The regional circumstances in Central and Eastern Europe are also very important and we must take them into account. Kremlin had decided to replace Brezhnev's doctrine of the limited sovreignity with so-called Sinatra Doctrine. Thus, the countries from Soviet sphere were able to choose their own ways and to build their own destinies. Gorbachev's peretroika and glasnost were perceived like a signal by them. So the refolutions from Poland, Hungary and Czechoslovakia will weaken and later determine the collapse of communism. It was practically impossible for Romanian communist regime to maintain a positive international image and to survive. An island of totalitarian communism could not survive being surrounded by states with democratic regimes. The domino principle was a reality. On the other hand, Nicolae Ceausescu's foreign policy was a paradoxical one. He turned to be a fervent Stalinist in internal affairs in order to consolidate his regime. At the same time, Romanian dictator remained loyal to his anti-Soviet attitude. He continued to follow this line in foreign policy even when it became obvious that it had become obsolete and catastrophic for him.

\section{References:}

1. Beschloss, M. , Talbott, S. (1993). At the Highest Levels. The Inside Story of the End of the Cold War. Boston, Toronto and London: Little, Brown and Company.

2. Burakowski, A. (2011). Dictatura lui Nicolae Ceausescu 1965-1989. Geniul Carpatilor. Translated into Romanian by Vasile Moga. Iaşi: Polirom.

3. Cartianu, G. (2010). Sfarsitul Ceausestilor. Bucharest: Editura Adevarul

4. Campeanu, P. (2002). Ceausescu, anii numaratorii inverse. Iasi: Polirom.

5. Deletant, D. (2006). Romania sub regimul comunist. Bucharest: Fundatia Academia Civica.

6. Idem (1997). Ceausescu si Securitatea: Constrangere si disidenta in Romania (1965-1989). Bucharest: Humanitas.

7. Evenimentul Zilei. December 16, 2009. Consulted on April 302012. http://www.evz.ro/detalii/stiri/ceausescu-se-voia-in-istorie-cavarianta-moderna-a-lui-stalin-880015.html

8. Gabanyi, A.U. (2003). Cultul lui Ceausescu. Translated into Romanian by Iulian Vamanu. Iasi: Polirom.

9. Gaddis, J.L. (2009). Razboiul Rece. Translated into Romanian by Diana Puscasu-TuTuianu. Bucharest: Rao International Publishing Company. 
10. Garton Ash, T. (1999). The Magic Lantern. The Revolution of 1989 Witnessed in Warsaw, Budapest, Berlin and Prague. New York: Vintage Books.

11. Georgescu, V. (1992). Istoria romanilor. De la origini pana in zilele noastre. Bucharest: Humanitas.

12. Gorun, A. (2012). Dezvoltarea sociala si globalizarea. Targu-Jiu: Editura „Academica Brancusi”.

13. Gorun, G. (2008). Rezistenta anticomunista in judetul Gorj reflectata in mentalul colectiv. Craiova: Editura Universitaria.

14. Gorun, H. (2012). Paradoxul politicii externe a lui Nicolae Ceausescu si motivele erodarii imaginii internationale a regimului sau. In Analele Universitatii din Craiova. Seria istorie (pp. 215-220), XVII, No. 2(22)/ 2012.

15. Jowitt, K. (1971). Revolutionary Breakthroughs and National Development: The Case of Romania. University of California Press.

16. Kligman, G. (2000). Politica duplicitatii. Controlul reproducerii in Romania lui Ceausescu. Translated into Romanian by Marilena Dumitrescu. Bucharest: Humanitas.

17. Kunze, T. (2002). Nicolae Ceausescu. O biografie. Translated into Romanian by Alexandru Teodorescu. Bucharest: Vremea.

18. Pacepa, I. M. (1993). Mostenirea Kremlinului, Bucharest: Editura Venus.

19. Idem (1992). Orizonturi rosii. Amintirile unui general de Securitate. Bucharest: Editura Venus.

20. Preda, D., Retegan, M. (2000). 1989 principiul dominoului: prabusirea regimurilor comuniste europene. Bucarest: Editura Fundaţiei Culturale Romane.

21. Retegan, M. (1998). 1968- Din primavara pana in toamna. Schita politica externa romaneasca, Bucharest: Rao.

22. Sandulescu, S. (1996). Decembrie 89. Lovitura de stat a confiscat revolutia romana. Bucharest: Colectia Document

23. Securitatea si cooperarea in Europa. Documente 1972-1989 (1991). Bucharest. Editura Academiei Romane

24. Shafir, M. (1985). Romania. Politics, Economics and Society. Political Stagnation and Simulated Change. London: Boulder Co.

25. Stoenescu, A. M. (2009). Cronologia evenimentelor din decembrie 1989. Bucharest: Rao.

26. Idem (2005). Istoria loviturilor de stat in Romania, vol. IV, Revolutia din decembrie 1989- o tragedie romaneasca. Bucharest: Rao.

27. Tismaneanu, V. (2005). Stalinism pentru eternitate. O istorie politica a comunismului romanesc. Translated into Romanian by Cristina Petrescu and Dragos Petrescu. Iasi: Polirom. 